\title{
STUDI ANATOMI STOMATA DAUN MANGGA (Mangifera indica) BERDASARKAN PERBEDAAN LINGKUNGAN
}

\author{
Asep Zainal Mutaqin ${ }^{1}$, Ruly Budiono ${ }^{2}$, Tia Setiawati ${ }^{3}$, Mohamad Nurzaman ${ }^{4}$, \\ Radewi Safira Fauzia ${ }^{5}$ \\ 1, 2, 3, 4, 5 Program Studi Biologi FMIPA Universitas Padjadjaran \\ J1. Raya Bandung-Sumedang Km. 21 Jatinangor 45363 Kabupaten Sumedang \\ email : 'asep.zainal.mutaqin@unpad.ac.id, ${ }^{2}$ rulybudiono7@gmail.com, \\ 3ia@unpad.ac.id, ${ }^{4}$ m.nurzaman@unpad.ac.id, ${ }^{5}$ radewisafira3@gmail.com
}

Diterima :25 Mei 2016 Ditinjau : 05 Oktober 2016 Disetujui :28 Oktober 2016

\begin{abstract}
Abstrak. Penelitian ini bertujuan untuk mengetahui stomata daun mangga (Mangifera indica) di daerah dengan kondisi lingkungan yang berbeda. Penelitian bersifat deskriptif analisis. Pengambilan sampel dilakukan melalui survey secara acak di Cagar Alam Pananjung Pangandaran dan salah satu ruas jalan di Kecamatan Pangandaran Kabupaten Pangandaran. Paramater yang diamati adalah kerapatan dan kerusakan stomata. Selain itu diukur juga luas daun, berat partikel debu yang menempel di daun, serta beberapa faktor lingkungan fisik seperti intensitas cahaya, suhu, dan kelembaban udara. Hasil penelitian menunjukkan bahwa kerapatan dan kerusakan stomata daun mangga (Mangifera indica) yang tumbuh di pinggir jalan yang banyak dilalui kendaraan bermotor lebih besar dibanding di Cagar Alam.
\end{abstract}

Kata kunci: stomata, Mangifera indica

\begin{abstract}
The study aims to determine the stomata of the leaves of mango (Mangifera indica) in areas with different environmental conditions. The research is descriptive analysis. Sampling was done through a random survey in Pananjung Pangandaran Nature Reserve and one of the roads in Pangandaran Sub District, Pangandaran District. The observed parameters are the density and stomatal damage. Moreover measured the leaf area, weight of the particles of dust off the leaves, as well as some physical environmental factors such as light intensity, temperature, and humidity. The results showed that the leaf stomatal density and damage to mango (Mangifera indica), which grows in the street that many passed the motor vehicle is greater than in the Nature Reserve.
\end{abstract}

Keywords: stomata, Mangifera indica

\section{PENDAHULUAN}

Pencemaran udara merupakan masalah yang serius dan semakin lama keberadaannya semakin meningkat. Pencemaran udara didefinisikan sebagai masuknya atau dimasukannya zat, energi, dan/ atau komponen lain ke dalam udara ambien oleh kegiatan manusia, sehingga mutu udara ambien turun sampai ke tingkat tertentu yang menyebabkan udara ambien tidak dapat memenuhi fungsinya. Sementara itu sumber pencemar berasal dari setiap usaha dan/ atau kegiatan yang mengeluarkan bahan pencemar ke udara yang menyebabkan udara tidak dapat berfungsi sebagaimana mestinya (Peraturan Pemerintah RI No. 41 Tahun 1999).
Peningkatan polusi udara pada umumnya diakibatkan adanya produksi listrik, emisi kendaraan, aktivitas industri, pertambahan kepadatan penduduk, kurangnya hutan atau taman kota, dan lain-lain. Umumnya pada jalan-jalan besar yang jauh dari daerah perindustrian, kontribusi polutan sebagian besar berasal dari hasil pembuangan kendaraan yang melewati jalan tersebut. Hasil-hasil buangan dari aktivitas industri dan transportasi di kota dibagi menjadi 2 bagian, yaitu gas dan partikulat. Pencemar gas antara lain berupa karbon monoksida $(\mathrm{CO})$, oksida sulfur $\left(\mathrm{SO}_{\mathrm{x}}\right)$, oksida nitrogen $\left(\mathrm{NO}_{\mathrm{x}}\right)$, dan hidrokarbon. Sedangkan partikulat berupa asap, kabut, dan debu (Satria, 2006). Sementara itu Kastiyowati (2001) menggolongkan jenis-jenis pencemaran 
udara berdasarkan (i) bentuk, yaitu gas dan partikel; (ii) tempat, yaitu ruangan dan udara bebas; (iii) gangguan kesehatan, yaitu iritansia, asfiksia, anestesia, dan toksik; serta asal, yaitu primer dan sekunder.

Udara yang tercemar perlu dipantau dan dikendalikan. Pengendalian pencemaran udara adalah upaya pencegahan dan/ atau penanggulangan pencemaran serta pemulihan mutu udara mestinya (Peraturan Pemerintah RI No. 41 Tahun 1999). Sementara itu Kovack (1992) dalam Romadhoni dan Ubudiyah (2011) menyebutkan bahwa salah satu cara pemantauan pencemaran udara adalah dengan menggunakan tumbuhan sebagai bioindikator. Tumbuhan adalah bioindikator pencemaran yang baik. Tumbuhan bioindikator berupa tumbuhan yang dapat memiliki daya serap yang lebih tinggi dibanding tumbuhan lainnya. Salah satu tumbuhan biondikator adalah mangga (Mangifera indica). Tumbuhan mangga (Mangifera indica) dapat dijadikan bioindikator pencemaran udara, dikarenakan memiliki daya serap yang tinggi untuk mengakumulasi karbondioksida. Karyadi pada tahun 2005 menyatakan bahwa mangga dapat menyerap 1,247 $\mathrm{kg} \mathrm{CO}_{2}$ per hari. Hal ini menunjukan bahwa tumbuhan mangga dapat mengakumulasi karbondioksida dalam jumlah yang sangat besar. Mangga (Mangifera indica) sering ditanam hampir di setiap lahan, tak terkecuali pinggir-pinggir jalan raya. Selain karena kemampuan menyerap karbondioksida tumbuhan ini juga memiliki manfaat lainnya seperti sebagai peneduh dan bernilai ekonomis dari buahnya.

Tingkat kepekaan tumbuhan berhubungan dengan kemampuannya untuk menyerap dan mengakumulasikan zat pencemar. Zat-zat pencemar akan terdifusi ke dalam daun melalui stomata yang juga dipengaruhi oleh keadaan udara di sekitarnya. Hal ini dikarena stomata berfungsi sebagai pintu gerbang pertukaran gas dan uap air antara tumbuhan dengan lingkungan sekitar (Rachmawati, 2006). Pencemaran udara di sekitar jalan raya yang salah satunya karena emisi kendaraan bermotor dapat mempengaruhi anatomi stomata atau dengan kata lain stomata merupakan bagian tumbuhan tempat terjadinya penyerapan zat pencemar (Satolom et al., 2013). Dengan demikian daun merupakan organ tumbuhan sebagai bioindikator yang paling peka terhadap lingkungan dengan melihat kerusakan secara makroskopis atau mikroskopis (anatomi) organ tumbuhan tersebut.

\section{BAHAN DAN METODE}

Penelitian bersifat deskriptif analisis. Pengambilan sampel dilakukan melalui survey secara acak di Cagar Alam Pananjung dan ruas Jalan Kidang Pananjung di Kecamatan Pangandaran Kabupaten Pangandaran. Pengambilan sampel daun di Jalan Kidang Pananjung tersebut karena diduga bahwa udara di tempat tersebut telah terkontaminasi oleh zat- zat pencemar secara berlebih. Sementara itu pengambilan sampel daun di Cagar Alam Pangandaran berdasarkan asumsi kondisi lingkungan udaranya masih belum banyak zat pencemar. Pengambilan sampel dilakukan pada pukul 10.00 WIB. Sampel yang diambil berjumlah 9 sampel pada satu pohon dalam kondisi naungan dan umur yang diasumsikan sama. Paramater yang diamati adalah kerapatan dan kerusakan stomata. Selain itu diukur juga luas daun, berat partikel debu yang menempel di daun. Data lingkungan di lokasi tempat ditemukannya spesies mangga (Mangifera indica) yang diambil sebagai sampel juga diukur. Adapun data lingkungan yang diambil di antaranya adalah intensitas cahaya, suhu, dan kelembaban udara.

Alat dan bahan yang digunakan dalam penelitian ini antara lain kaca objek, penggaris, neraca analitis, lux meter, termometer, hygrometer, GPS, handly counter, alat tulis, kamera, mikroskop, plastik ziploks, kuteks, selotip, dan kertas milimeter blok.

Langkah kerja yang dilakukan dalam penelitian ini adalah (i) Pengukuran data fisik dilakukan bersamaan dengan pengambilan sampel, (ii) berat partikel debu dihitung dengan cara, daun sampel ditimbang kemudian dibersihkan daunnya menggunakan kapas dan ditimbang kembali. Selisih berat daun sebelum dibersihkan dengan sesudah dibersihkan merupakan berat partikel debu tersebut, (iii) luas daun dihitung dengan metode gravitimeter, yaitu daun dibersihkan dari berbagai kotoran. Selanjutnya ketebalan daun diukur dan dilanjutkan dengan pembuatan 
replika daun di atas kertas milimeter blok. Replika daun digunting dan ditimbang beratnya, lalu dibandingkan dengan berat total kertas. Luas daun dihitung berdasarkan persamaan:

Berat kertas replika daun $\times$ Luas total kertas Berat total kertas

(Sitompul dan Guritno, 1995)

(iv) Pengamatan anatomi stomata. Permukaan sampel dibersihkan menggunaan kapas yang dibasahi oleh air. Dibuat preparat stomata dari sampel daun tersebut menggunakan kuteks. Preparat stomata diamati di bawah mikroskop. Dihitung persentase kerusakan dan kerapatan stomata. Kerusakan stomata dihitung dengan rumus:

Kerapatan stomata $=\underline{\text { Jumlah stomata }}$

Luas bidang pandang ${ }^{(*)}$
Sementara itu kerapatan stomata, yang diadopsi dari Lestari (2006), dihitung dengan rumus:

Jumlah stomata yang rusak $\times 100 \%$

Jumlah stomata yang diamati

Dimana, luas bidang pandang untuk perbesaran $400 \mathrm{x}=1 / 4 \pi \mathrm{d}^{2}=1 / 4 \times 3,14 \times(0,5)^{2}$ $=0,19625 \mathrm{~mm}^{2}$

\section{HASIL}

Hasil pengamatan stomata sampel daun, luas daun, berat partikel debu yang menempel di daun, serta beberapa faktor lingkungan dapat dilihat pada Tabel 1, Tabel 2, dan Gambar 1 di bawah ini:

Tabel 1. Data Pengamatan Stomata, Berat Partikel Debu, serta Luas Daun Mangifera indica di Lingkungan yang Berbeda

\begin{tabular}{ccccc} 
& $\begin{array}{c}\text { Kerusakan } \\
\text { stomata }(\%)\end{array}$ & $\begin{array}{c}\text { Kerapatan stomata } \\
\left(\mathrm{jml} / \mathrm{mm}^{2}\right)\end{array}$ & $\begin{array}{c}\text { Berat partikel } \\
\text { debu }(\mathrm{g})\end{array}$ & $\begin{array}{c}\text { Luas daun } \\
\left(\mathrm{cm}^{2}\right)\end{array}$ \\
\hline Jalan Kidang Pananjung & 39,61 & 547 & 0,04 & 9,5 \\
Cagar Alam Pananjung & 16,1 & 280 & 0,02 & 9,6 \\
\hline
\end{tabular}

Tabel 2. Data Pengukuran Lingkungan Fisik di Lokasi Pengambilan Sampel Daun Mangifera indica

\begin{tabular}{|c|c|c|}
\hline Data fisik & Jalan Kidang Pananjung & Cagar Alam Pangandaran \\
\hline Titik koordinat & S 07"42’04.16" E 108 39'27.92" & S $07^{0} 42^{\prime} 19.85^{\prime \prime}$ E $108^{0} 39^{\prime} 38.63^{\prime \prime}$ \\
\hline Intensitas cahaya & $109 \times 100 \operatorname{lux}$ & $30 \times 100 \operatorname{lux}$ \\
\hline Kelembaban & $76 \%$ & $71 \%$ \\
\hline Suhu & $31,8^{0} \mathrm{C}$ & $32,1^{0} \mathrm{C}$ \\
\hline Jumlah kendaraan & 5400 & - \\
\hline Kecepatan angin & $2 \mathrm{~m} / \mathrm{s}$ & $0,3 \mathrm{~m} / \mathrm{s}$ \\
\hline
\end{tabular}

Bentuk stomata abnormal

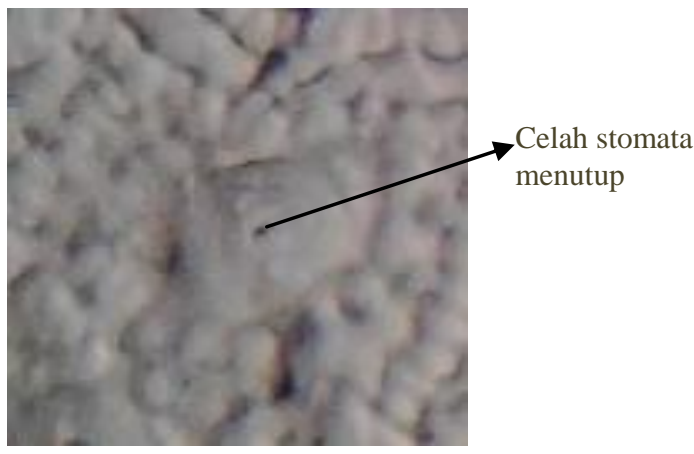

Mikroskop cahaya

Perbesaran $400 \mathrm{x}$

Tipe stomata : anomositik

Lokasi sampel : Jalan Kidang Pananjung Pangandaran

Waktu pengambilan sampel : $10.00 \mathrm{WIB}$
Bentuk stomata normal

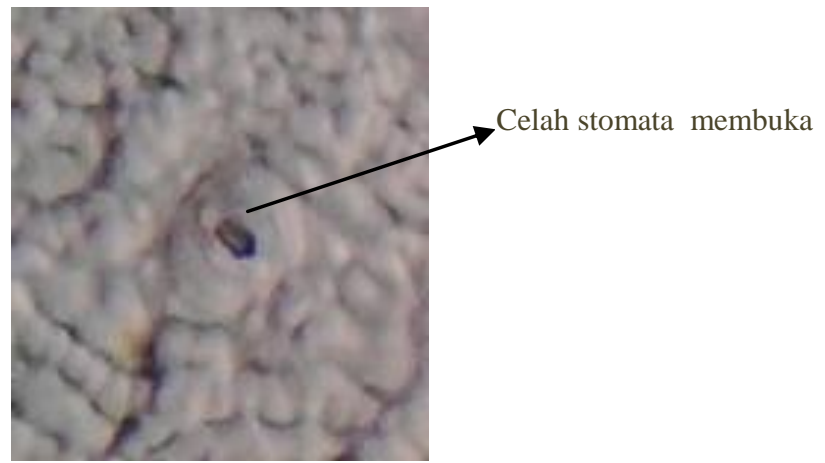

Mikroskop cahaya

Perbesaran : $400 \mathrm{x}$

Tipe stomata : anomositik

Lokasi sampel : Cagar Alam Pananjung Pangandaran

Waktu pengambilan sampel : $10.00 \mathrm{WIB}$

Gambar 1. Anatomi Stomata Sampel Daun Mangifera indica 


\section{PEMBAHASAN}

Pada hasil yang tertera pada Tabel 1 terlihat adanya perbedaan persentase kerusakan stomata pada daun mangga (Mangifera indica) yang berada di pinggir Jalan Kidang Pananjung dengan di Cagar Alam Pananjung. Pada stomata di pinggir jalan memiliki persentase kerusakan stomata lebih besar, yaitu sebesar 39,61\% dibandingkan dengan kerusakan stomata pada daun mangga di cagar alam sebesar $16,1 \%$. Hal ini mengindikasikan bahwa pencemaran udara berpengaruh terhadap tumbuhan, khususnya dalam proses membuka dan menutupnya stomata. Pada saat stomata membuka, dimana kondisi udara lembab, maka gas-gas yang ada di udara yang terserap tumbuhan akan menyebabkan menutupnya stomata, akibat akumulasi polutan pada sel penutup, sel penjaga, serta jaringan mesofil dan mempengaruhi kinerja ion-ion dalam proses fotosintesis (Romadhoni dan Ubudiyah, 2011). Hal senada dinyatakan oleh Solihin (2014) bahwa pemaparan emisi kendaraan bermotor terhadap tumbuhan dapat meningkatkan tingginya persentase menutupnya celah stomata di samping rendahnya kadar klorofil dan adanya kerusakan morfologi daun.

Perbedaan signifikan juga terdapat pada nilai kerapatan stomata daun mangga pada tempat berbeda. Pada stomata daun mangga di pinggir jalan memiliki kerapatan stomata lebih besar dari stomata daun mangga di cagar alam. Kerapatan stomata juga dipengaruhi oleh pencemaran udara. Hal ini merupakan bentuk adaptasi fisiologis akibat pencemaran udara. Polutan yang menempel pada stomata akan terakumulasi dan apabila dalam jumlah yang besar dapat merusak sel-sel stomata. Sel-sel stomata yang rusak akan merangsang produksi stomata dalam jumlah yang lebih banyak agar proses fotosintesis berjalan dengan normal sebagai bentuk adaptasi. Gunarno (2014) menyatakan bahwa jumlah stomata di daerah tercemar lebih tinggi disbanding di daerah tidak tercemar. Lebih umum, Prawiranata, et al. (1995) menyebutkan bahwa keadaan lingkungan mempengaruhi frekuensi stomata. Daun tanaman yang tumbuh pada lingkungan kering dan dibawah cahaya dengan intensitas tinggi cenderung memiliki stomata yang banyak. Fahn (1991) juga mengemukakan bahwa jumlah stomata akan berkurang dengan menurunnya intensitas cahaya. Berdasarkan pengamatan, tercatat intensitas cahaya di kedua lokasi pengambilan sampel sangat berbeda, yaitu sebesar 109 x 100 lux di pinggir Jalan Kidang Pananjung dan 30 x 100 lux di Cagar Alam Pananjung. Dengan demikian, kerapatan stomata selain dipengaruhi oleh zat pencemar, juga dipengaruhi oleh intensitas cahaya. Intensitas cahaya dipengaruhi faktor penutupan vegetasi. Tumbuhan dipengaruhi oleh beberapa faktor lingkungan seperti cahaya matahari, suhu, kelembaban udara, nutrisi tanah, naungan, bentuk pertumbuhan, dan kompetitor (Levy, 1955; Mcilroy, 1976).

Berdasarkan pengukuran, berat partikel debu pada sampel daun di kedua tempat menunjukkan jumlah yang berbeda, di mana berat partikulat debu pada daun di Jalan Kidang Pananjung lebih besar daripada di Cagar Alam Pananjung. Hal ini dimungkinkan banyak partikel debu yang menempel di Jalan Kidang Pananjung sebagai akibat emisi dari kendaraan bermotor atau aktivitas manusia lainnya. Satria (2006) menyebutkan bahwa hasil buangan dari aktivitas industri dan transportasi adalah gas dan partikulat. Pencemar gas antara lain berupa karbon monoksida (CO), oksida sulfur (SOx), oksida nitrogen (NOx), dan hidrokarbon. Sedangkan partikulat berupa asap, kabut, dan debu. Lebih khusus, partikulat debu dipengaruhi oleh faktor kecepatan angin. Kecepatan angin yang terukur di Jalan Kidang Pananjung adalah 2 $\mathrm{m} / \mathrm{s}$ dan di Cagar Alam Pananjung adalah sebesar 0,3 m/s. Rachmawati (2006) mengungkapkan bahwa makin rendah kecepatan angin, penyebaran bahan pencemar semakin rendah, sehingga konsentrasi pencemar yang menempel di daun suatu tumbuhan semakin sedikit. Namun tidak disimpulkan bahwa partikulat mempengaruhi kerusakan stomata atau dengan kata lain kerusakan anatomi stomata lebih dipengaruhi oleh zat pencemar lain, terutama dari emisi kendaraan bermotor. Berdasarkan perhitungan, jumah kendaraan bermotor yang melintasi di Jalan Kidang Pananjung adalah sebanyak ratarata 5400 buah per hari. Sutiawan, et al. (2014) menyebutkan bahwa jumlah kendaraan bermotor sebesar 3.029 buah per hari dapat 
menghasilkan $2.290,39 \mu \mathrm{g} / \mathrm{Nm}^{3} \mathrm{~g}$ emisi gas buangan. Dengan demikian, maka dalam sehari dihasilkan emisi sekitar $0,76 \mu \mathrm{g} / \mathrm{Nm}^{3}$ dalam satu kendaraan. Selanjutnya, apabila terdapat 5400 buah kendaraan, maka dihasilkan emisi gas buangan sebesar 4.104 $\mu \mathrm{g} / \mathrm{Nm}^{3}$, walaupun jika dibandingkan dengan baku mutu udara dalam Peraturan Menteri Negara Lingkungan Hidup No. 12 Tahun 2010 masih tergolong aman.

Hasil pengukuran luas daun pada sampel yang diambil dari kedua tempat tidak menunjukkan perbedaan yang signifikan. Belum diketahui secara jelas pengaruh zat pencemar terhadap luas daun. Namu Gunarno (2014) menyatakan bahwa luas daun di daerah tidak tercemar lebih besar dibanding di daerah tercemar. Lebih umum, Daniel, et al. (1992) dalam Irwanto (2006) menyebutkan bahwa faktor lingkungan lain, yaitu cahaya dapat mempengaruhi langsung pertumbuhan tumbuhan. Selanjutnya Fitter dan Hay (1994) menyebutkan bahwa luas daun dapat dipengaruhi oleh intensitas cahaya matahari. Lebih khusus, Abidin (1993) menyebutkan bahwa intensitas cahaya yang terlalu besar dapat menyebabkan jumlah hormon auksin di daun menjadi lebih sedikit, sehingga menyebabkan daun tumbuh menjadi kecil. Bahkan Ardhana (2012) menyebutkan bahwa salah satu bentuk adaptasi tumbuhan untuk menghindari pelayuan daun akibat transpirasi yang dipicu karena paparan intensitas cahaya yang tinggi adalah dengan ukuran daun yang kecil dan tebal. Sebaliknya, bentuk adaptasi dari tumbuhan terhadap kondisi lingkungan dengan intensitas cahaya yang rendah, tumbuhan memiliki luas daun yang lebih lebar, pengurangan respirasi, dan peningkatan kecepatan fotosintesis (Fitter dan Hay, 1994). Hal senada disebutkan oleh Ducrey (1992 dalam Marjenah, 2001) bahwa tumbuhan melakukan adaptasi morfologi sebagai respon terhadap intensitas cahaya rendah dengan ditandai luas daun yang lebih lebar dibandingkan dengan yang tumbuh di daerah dengan intensitas cahaya yang lebih besar.

Hasil pengukuran suhu lingkungan di tempat pengambilan sampel menunjukkan hasil yang tidak terlalu jauh berbeda. Namun Jumin (2002 dalam Ardhana, 2012) menyebutkan bahwa suhu yang terlalu tinggi dapat menyebabkan tumbuhan melakukan adaptasi dengan luas daun yang tidak lebar. Selain itu, Croxdale (2000 dalam Onrizal, 2005) menyatakan bahwa intensitas yang tinggi akan menyebabkan suhu lingkungan menjadi tinggi pula yang dapat menyebabkan peningkatan proses transpirasi.

Berdasarkan hasil dan pembahasan di atas, maka dapat disimpulkan bahwa kerapatan dan kerusakan stomata daun mangga (Mangifera indica) dapat dipengaruhi oleh kondisi lingkungan, di mana kerapatan dan kerusakan stomata daun mangga (Mangifera indica) yang tumbuh di pinggir Jalan Kidang Pananjung yang banyak dilalui kendaraan bermotor atau aktivitas manusia lainnya lebih besar dibanding di Cagar Alam Pananjung.

\section{UCAPAN TERIMA KASIH}

Hasil penelitian ini merupakan karya ilmiah yang tidak hanya melibatkan diri penulis secara personal. Dengan demikian penulis mengucapkan banyak terima kasih kepada semua pihak yang telah mendukung penelitian ini, baik itu perseorangan ataupun institusi.

\section{DAFTAR PUSTAKA}

Abidin, Z., 1993. Dasar-dasar Pengetahuan tentang Zat Pengatur Tumbuh. Cetakan ke-3. Angkasa. Bandung.

Ardhana, I. P. G., 2012. Ekologi Tumbuhan. Cetakan pertama. Udayana University Press. Denpasar.

Fahn, A. 1991. Anatomi Tumbuhan. Gajah Mada University Press. Yogyakarta.

Fitter, A. H. \& Hay, R. K. M., 1994. Fisiologi Lingkungan Tanaman. Penerjemah Sri Andani dan E. D. Purbayanti. Cetakan ketiga. Gadjah Mada University Press. Yogyakarta.

Gunarno. 2014. Pengaruh Pencemaran Udara terhadap Luas Daun dan Stomata Daun Rhoeo discolor. http: //sumut. kemenag. go.id/file/file/TULISANPENGAJAR/ $w d f 1414044644 . p d f$. Diakses pada tanggal 25 Mei 2016.

Irwanto. 2006. Pengaruh Perbedaan Naungan terhadap Pertumbuhan Semai Shorea sp. 
di Persemaian. Tesis. Sekolah Pascasarjana UGM. Yogyakarta.

Karyadi, H. 2005. Pengukuran Daya Serap Karbondioksida Lima Jenis Tanaman Hutan Kota. Skripsi. Departemen Konservasi Sumberdaya Hutan dan Ekowisata. Fakultas Kehutanan. IPB. Bogor.

Kastiyowati, I. 2001. Dampak dan Upaya Penanggulangan Pencemaran Udara. Puslitbang Tek Balitbang Dephan. Jakarta.

Lestari, E. G. 2006. Hubungan antara Stomata dengan Ketahanan Kekeringan pada Somaklon Padi Gajahmungkur, Towuti, dan IR 64. Biodiversitas 7(1): 44-48.

Marjenah. 2001. Pengaruh Perbedaan Naungan di Persemaian terhadap Pertumbuhan dan Respon Morfologi Dua Jenis Semai Meranti. Jurnal Ilmiah Kehutanan "Rimba Kalimantan" 6 (2).

Mcilroy, R. J. 1976. Pengantar Budidaya Padang Rumput Tropika. Pradnya Paramita. Jakarta.

Onrizal. 2005. Adaptasi Tumbuhan Mangrove pada Lingkungan Salin dan Jenuh Air. Jurnal Penelitian USU Repository 2-13.

Peraturan Menteri Negara Lingkungan Hidup No. 12 Tahun 2010 tentang Pelaksanaan Pengendalian Pencemaran Udara di Daerah.

Peraturan Pemerintah Republik Indonesia No. 41 Tahun 1999 tentang Pengendalian Pencemaran Udara.

Prawiranata, Said Harran, dan Pin Tjondronegoro. $1995 . \quad$ Fisiologi Tumbuhan. Jilid 2. IPB. Bogor.

Rachmawati. 2006. Uji Pencemaran Udara oleh Partikulat Debu di Sekitar Terminal Lebak Bulus Berdasarkan Bioindikator Stomata pada Tanaman Glodogan (Polyalthia longifolia). Skripsi. Jurusan
Biologi Fakultas Sains dan Teknologi Universitas Islam Negeri Syarif Hidayatullah. Jakarta.

Romadhoni, M. dan I. W. A. Ubudiyah. 2011. Pengaruh Polusi Udara terhadap Stomata Daun Angsana (Pterocarpus indicus). http://muhammadromadhoni.blogspot.co.i d/2011/11/pengaruh-polusi-udaraterhadap-stomata.html. Diakses pada 24 Mei 2016.

Satria, N. 2006. Pendugaan Konsentrasi Karbon Monoksida (CO) dari Sumber Garis (Transportasi) Menggunakan BoxModel "Street Canyon". Skirpsi. Departemen Geofisika dan Meteorologi. Fakustas Matematika dan Ilmu Pengetahuan Alam. IPB. Bogor.

Satolom, A. W., N. Y. Kandowangko, dan A. S. Katili. 2013. Analisis Kadar Klorofil, Indeks Stomata dan Luas Daun Tumbuhan Mahoni (Swietenia macrophylla King.) pada Beberapa Jalan di Gorontalo. http://kim.ung.ac.id/index.php/KIMFMIP A/article/view/3700. Diakses pada $25 \mathrm{Mei}$ 2016.

Sitompul, S.M. dan Guritno, B. 1995. Analisa Pertumbuhan Tanaman. Yogyakarta: Gadjah Mada University Press.

Solihin, A. 2014. Morfologi Daun, Kadar Klorofil, dan Stomata Glodokan (Polyalthia longifolia) pada Daerah dengan Tingkat Paparan Emisi Kendaraan yang Berbeda di Yogyakarta. Skripsi. Program Studi Biologi Fakultas Sains dan Teknologi Universitas Islam Negeri Sunan Kalijaga. Yogyakarta

Sutiawan, A.,Yulisa F., Eti S. 2014. Hubungan Faktor Meteorologi terhadap Tingkat Konsentrasi Karbon Monoksida (CO) di Jalan Kota Pontianak. 1(1): 5-9. 